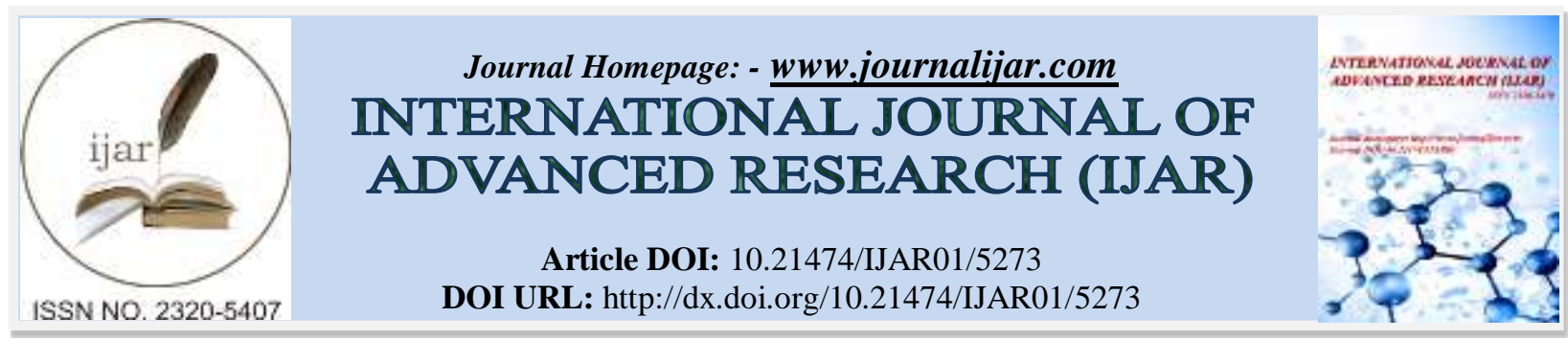

RESEARCH ARTICLE

\title{
ANALYSIS AND SIMULATION OF PV FED MULTI-LEVEL INVERTER.
}

\author{
G. Jotheeshwari ${ }^{1}$ and T. S. Anandhi ${ }^{2}$. \\ 1. Research scholar, Department of electronics and instrumentation engineering, annamalai university. \\ 2. Associate professor, Department of electronics and instrumentation engineering, annamalai university.
}

\section{Manuscript Info}

Manuscript History

Received: 24 June 2017

Final Accepted: 26 July 2017

Published: August 2017

Key words:-

Photovoltaic module, DC-DC Converter, Maximum power point tracking,

Multilevel inverter, Multicarrier PWM

\begin{abstract}
Design and simulation of PV fed Multi-Level Inverter (MLI) through the DC-DC converter in Continuous Conduction Mode (CCM) have been carried out in this work. The voltage regulated PV fed DC-DC power converter is used as DC source for the MLI . Multicarrier PWM switching strategies are used for the selected seven level asymmetric MLI. The mathematical model of PV system and DC-DC converter have been presented and verified under varying climatic and load conditions. To improve the performance of the PV system, PI controller PWM control scheme and on-line INC MPPT algorithm with fixed and variable step size has been developed. Simulations are carried out using MATLAB/SIMULINK Simpower System block set .In variable step size MPPT method the PI controller modifies the step size enabling faster tracking of the maximum input power and shows the improvement in the efficiency of energy utilization. The developed setup is fed to the two H-Bridge cascaded asymmetric MLI to generate 7-level sinusoidal AC output .
\end{abstract}

Copy Right, IJAR, 2017,. All rights reserved.

\section{Introduction:-}

Applications of PV sources are mostly in battery charging, water pumping, house appliances and satellite power system etc. Photovoltaic (PV) modules are formed by series connections of cells to obtain the desired high voltage. The mathematical model of the PV source is developed. The simulation results of the modeled PV under variable climatic conditions such as temperature and irradiation are also analyzed. PV system exhibits nonlinear characteristics I-V and P-V. They vary with irradiation and cell temperature. The output current varies linearly with the solar irradiance. PV model under varying input parameters say irradiation and temperature lead to change in load voltage of the buck converter. Increased cell's temperature variation decreases the open circuit voltage and increased solar irradiation variation increases the open circuit voltage thus improving the power generation during the midday than the early morning \& evening. To improve the efficiency, the PV module has to be operated at maximum power even under varying temperature and irradiation conditions. This can be achieved by matching PV source with the load for all varying atmospheric conditions. by using the MPPT technique.

\section{Mathematical Model Of Pv System:-}

The general PV cell model can be modelled as a current source and a diode connected in parallel, shunt resistor and a series resistor describes the leakage current, and internal resistance to the current flow, is shown in Fig. 1.

Corresponding Author:- G. Jotheeshwari.

Address:- Research scholar, Department of electronics and instrumentation engineering, annamalai university. 


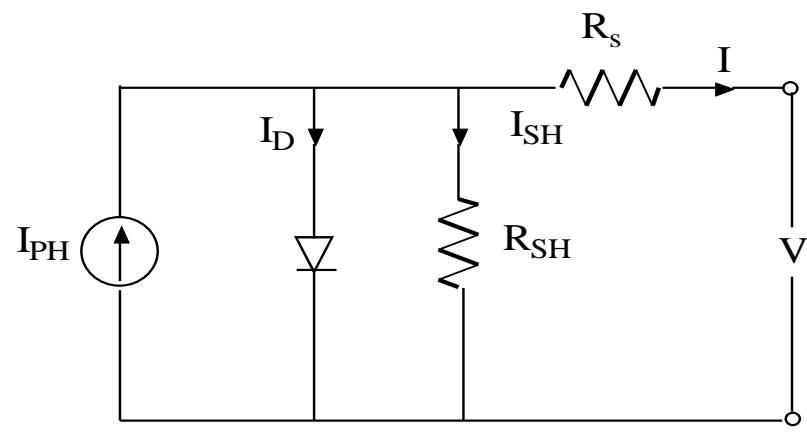

Fig. 1:- PV Cell General Model.

Applying the Kirchhoff current law the output current of the PV cell is given by the following equation.

$$
\begin{aligned}
& I=I_{P H}-I_{D}-I_{S H} \\
& I_{D}=I_{S}\left[\exp \left(\frac{q\left(V+I R_{s}\right)}{k A T_{C}}\right)-1\right] \\
& I_{S H}=\frac{V+I R_{s}}{R_{S H}}
\end{aligned}
$$

Substitute equation (3.2) and (3.3) in (3.1) we get

$$
I=I_{P H}-I_{S}\left[\exp \left(\frac{q^{*}\left(V+I R_{s}\right)}{k A T_{C}}\right)-1\right]-\frac{V+I R_{s}}{R_{S H}}
$$

$\mathrm{PV}$ cell produces less than $2 \mathrm{~W}$ at $0.58 \mathrm{~V}$ approximately. To meet the sufficient power, the series/parallel connection of the PV cell to form the modules is necessary.

$$
I=N_{P} I_{P H}-N_{P} I_{S}\left[\exp \left(\frac{q\left(V+I R_{s}\right)}{N_{S} k A T_{C}}\right)-1\right]-\frac{V+I R_{s}}{R_{S H}}
$$

where $I_{P H}$ is a light generated current or photo current, $I_{D}$ is the diode current, $I_{S H}$ is the shunt current, $I_{S}$ is the cell saturation of dark current, $T_{C}$ is the cell's working temperature, $N_{S}$ is the number of series cells, $N_{P}$ is the number of parallel cells, $R_{\mathrm{SH}}$ is a shunt resistance, $\mathrm{R}_{\mathrm{s}}$ is a series resistance, $\mathrm{q}\left(=1.6 \times 10^{-19} \mathrm{C}\right)$ is an electron charge, $\mathrm{k}(=$ $\left.1.3805 \times 10^{-23} \mathrm{~J} / \mathrm{K}\right)$ is a Boltzmann's constant and A $\left(=1.3 \mathrm{Si}\right.$-poly) is an ideal factor. The $\mathrm{I}_{\mathrm{PH}}$ depends on the PV cell's temperature and solar irradiation is represented as.

$$
\begin{aligned}
& I_{P H}=\left[I_{S C}+K_{I}\left(T_{C}-T_{\operatorname{Re} f}\right)\right] G / 1000 \\
& I_{S}=I_{R S}\left(\frac{T_{C}}{T_{\operatorname{Re} f}}\right)^{3}\left[\exp \left[\left(\frac{q E_{G}}{k A}\right)\left(\frac{1}{T_{\operatorname{Re} f}}-\frac{1}{T_{C}}\right)\right]\right] \\
& I_{R S}=\frac{I_{S C}}{\left[\exp \left(\frac{q V_{O C}}{N_{S} k A T_{C}}\right)-1\right]}
\end{aligned}
$$

where $\mathrm{I}_{\mathrm{SC}}$ is the cell's short-circuit current under standard test conditions (STCs) using $25^{\circ} \mathrm{C}$ and $1000 \mathrm{~W} / \mathrm{m}^{2}, \mathrm{~K}_{\mathrm{I}}$ is the cell's short-circuit current temperature coefficient, $T_{R e f}$ is the cell's reference temperature and $G$ is the solar irradiation in $\mathrm{W} / \mathrm{m}^{2}, \mathrm{E}_{\mathrm{G}}(=1.12 \mathrm{eV})$ is the semiconductor band-gap energy of the cell, $\mathrm{I}_{\mathrm{RS}}$ is the cell's reverse saturation current and $\mathrm{V}_{\mathrm{OC}}$ is the open-circuit voltage under STC. 
$I=N_{P M} N_{P} I_{P H}-N_{P M} N_{P} I_{S}\left[\exp \left(\frac{q\left(V+I R_{s} \times \frac{N_{S M}}{N_{P M}}\right)}{N_{S} k A T_{C} N_{S M}}\right)-1\right]-\frac{V+I R_{s} \times \frac{N_{S M}}{N_{P M}}}{R_{S H} \times \frac{N_{S M}}{N_{P M}}}$

$N_{P M}$ and $N_{S M}$ represents the parallel and series modules. $R_{S}$ and $R_{S H}$ is varied by iterative process until the experimental data fits with $\mathrm{I}-\mathrm{V}$ curve as shown in the flow chart. $P_{\max m}=P_{\max e}=V_{m p}\left\{I_{P H}-I_{S}\left[\exp \left(\frac{q\left(V_{m p}+R_{s} I_{m p}\right)}{N_{s} A k T_{C}}\right)-1\right]-\frac{V_{m p}+R_{s} I_{m p}}{R_{S H}}\right\}$

$R_{S H}=\frac{V_{m p}\left(V_{m p}+I_{m p} R_{s}\right)}{\left\{V_{m p} I_{P H}-V_{m p} I_{S}\left[\exp \left(\frac{q\left(V_{m p}+I_{m p} R_{s}\right)}{N_{s} k A T_{C}}\right)\right]+V_{m p} I_{S}-P_{\max e}\right\}}$

$I_{S C}=\frac{R_{S H}+R_{s}}{R_{S H}} I_{S C}$

$R_{S H \text { min }}=\frac{V_{m p}}{I_{S C}-I_{m p}}-\frac{V_{O C}-V_{m p}}{I_{m p}}$

The values of $R_{S}$ and $R_{S H}$ are initially unknown but as the solution of the algorithm is refined along successive iterations the values of $R_{S}$ and $R_{S H}$ tend to the best solution. The iterative method gives the solution $R_{S}=0.25 \Omega$ and $\mathrm{R}_{\mathrm{SH}}=56.72 \Omega$ and other parameters are identified from the manufacture's data specification of a KCP 12060 solar module under standard test conditions (STCs) of solar irradiation and temperature at $1000 \mathrm{~W} / \mathrm{m}^{2}$ and $25^{\circ} \mathrm{C}$ respectively as shown in Table 1 . The PV module is modeled by simulation using Matlab/SIMULINK.

Table 1:- Data Specification of KCP 12060 Module

\begin{tabular}{|l|c|}
\hline \multicolumn{1}{|c|}{ Parameters } & Values \\
\hline Open circuit voltage $\mathrm{V}_{\mathrm{OC}}$ & $21.20 \mathrm{~V}$ \\
\hline Short circuit current $\mathrm{I}_{\mathrm{SC}}$ & $4.03 \mathrm{~A}$ \\
\hline Voltage at maximum power $\mathrm{V}_{\mathrm{mp}}$ & $17 \mathrm{~V}$ \\
\hline Current at maximum power $\mathrm{I}_{\mathrm{mp}}$ & $3.50 \mathrm{~A}$ \\
\hline Maximum power $\mathrm{P}_{\max }$ & $59.5 \mathrm{~W}$ \\
\hline Current temperature coefficient $\mathrm{K}_{\mathrm{I}}$ & $2.80 \mathrm{~mA} /{ }^{\circ} \mathrm{C}$ \\
\hline Number of cell's in series $\mathrm{N}_{\mathrm{s}}$ & 36 \\
\hline Number of cell's in parallel $\mathrm{N}_{\mathrm{p}}$ & 1 \\
\hline
\end{tabular}




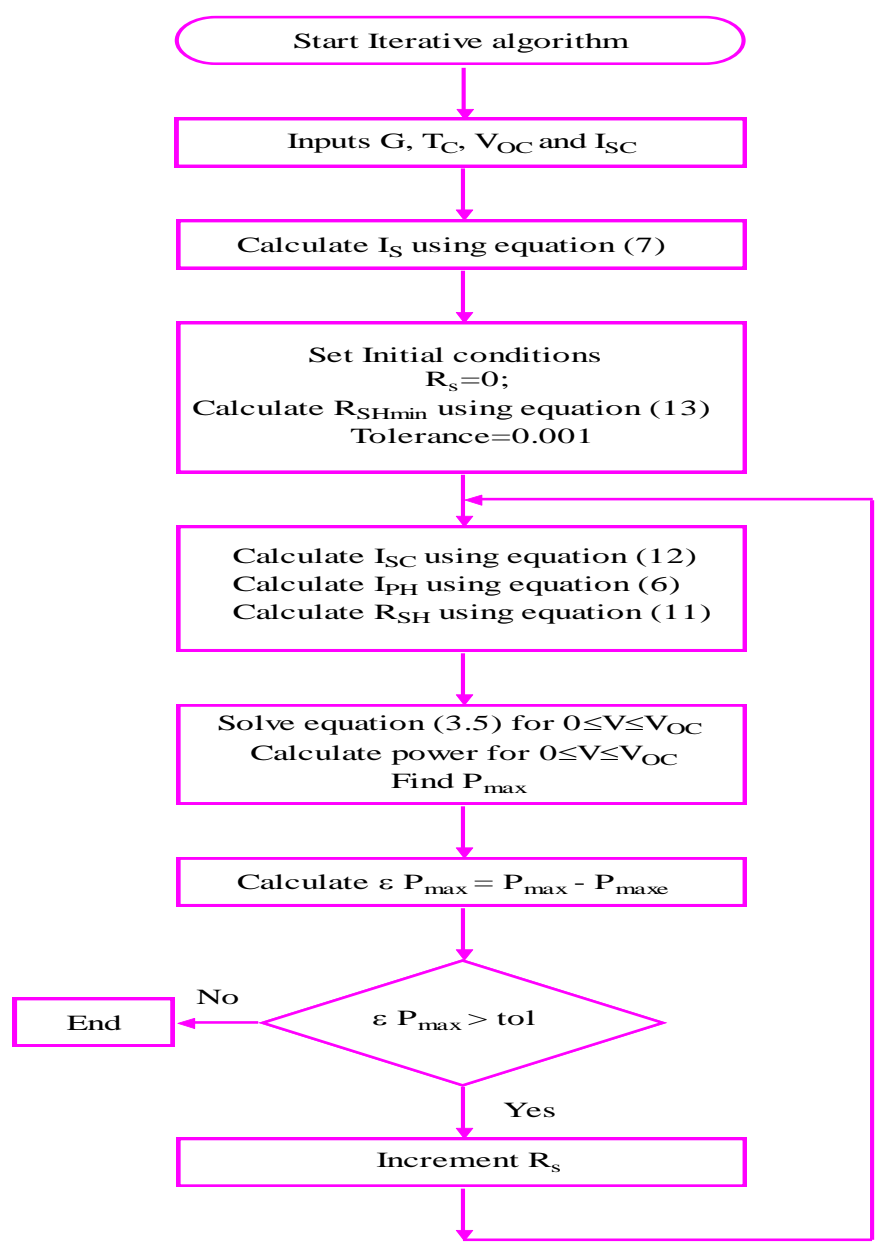

Fig. 2:- Iterative Algorithm to Adjust I-V Characteristics of PV Model

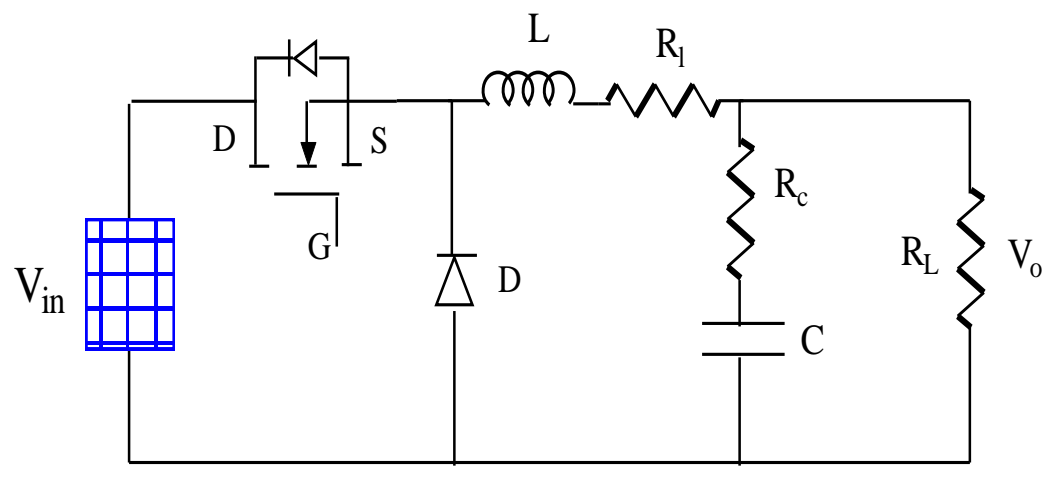

Fig. 3 Buck Converter

Table 2:- Specification of Buck Converter for Simulation Studies

\begin{tabular}{|c|c|c|}
\hline \multicolumn{2}{|c|}{ Data specifications of buck DC-DC converter } \\
\hline Parameters & $1^{\text {st }}-\mathrm{H}$ bridges & $2^{\text {nd }}-\mathrm{H}$ bridges \\
\hline Switching frequency $(\mathrm{f})$ & $20 \mathrm{Khz}$ & $20 \mathrm{Khz}$ \\
\hline PV Input voltage $\left(\mathrm{V}_{\text {in }}\right)$ & $21 \mathrm{~V}$ & $42 \mathrm{~V}$ \\
\hline Output voltage $\left(\mathrm{V}_{\mathrm{o}}\right)$ & $12 \mathrm{~V}$ & $24 \mathrm{~V}$ \\
\hline Inductance $(\mathrm{L})$ & $1.8 \mathrm{mH}$ & $3.6 \mathrm{mH}$ \\
\hline Capacitance $(\mathrm{C})$ & $107 \mu \mathrm{F}$ & $97 \mu \mathrm{F}$ \\
\hline
\end{tabular}




\begin{tabular}{|c|c|c|}
\hline Inductor series resistance $\left(\mathrm{R}_{\mathrm{i}}\right)$ & $1 \mathrm{~m} \Omega$ & $1 \mathrm{~m} \Omega$ \\
\hline Capacitor series resistance $\left(\mathrm{R}_{\mathrm{c}}\right)$ & $0.6 \Omega$ & $0.6 \Omega$ \\
\hline
\end{tabular}

The basic circuit of a buck converter is shown in Fig. 3 and its parameters chosen for simulation studies are shown in Table 2. The average output voltage $\mathrm{V}_{\mathrm{o}}$ is given by

$$
V_{o}=V_{\text {in }} \frac{T_{\text {on }}}{T_{\text {on }}+T_{\text {off }}}
$$

where, $\mathrm{T}_{\text {on }}$ on time period, $\mathrm{T}_{\text {off }}$ off time period of the semi conductor switch and $\mathrm{V}_{\mathrm{in}}$ is the input supply voltage .The simplified transfer function by the small signal model of the duty

cycle $\mathrm{d}$ to output $\mathrm{V}_{\mathrm{o}}$ is as

$$
\frac{\hat{V}_{o}}{\hat{d}}=\frac{V_{\text {in }} R_{L} d}{\left(R_{L}+R_{i}\right)}\left[\frac{1+s C R_{c}}{\left.s^{2} L C\left[\frac{R_{L}+R_{c}}{R_{L}+R_{i}}\right]+s\left[\left[\frac{L}{\left(R_{L}+R_{i}\right)}\right]+C\left[R_{c}+\left(\frac{R_{L} R_{i}}{R_{L}+R_{i}}\right)\right]\right]+1\right]}\right]
$$

\section{Pwm Control Techniques:-}

The PI controller is tuned by applying Zeigler Nicholas method applied to the approximately linearized buck model. The purpose of the controller is to influence the behavior of a system towards the desired set point under deviation due to the load or set point change. Fig. 4 show the open loop step response of the buck DC-DC converter for a constant temperature and irradiation in PV .

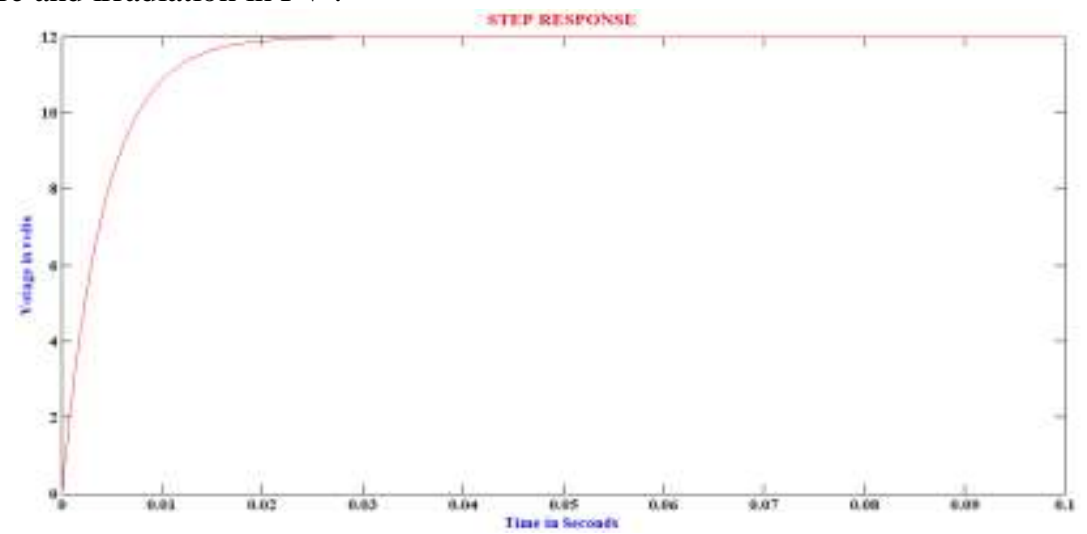

Figure 4:- Open Loop Step Response of Buck DC-DC Converter

\section{On-Line Incremental \& Conductance (I\&C) Mppt Algorithm:-}

Two on-line MPPT methods are available say perturb \& observation (P\&O) method and Incremental and conductance (I\&C) method. The INC tracks the maximum power more than the P\&O method even under fast varying weather conditions (Go et al 2011).In this work direct duty ratio INC method is used. The duty cycle of the converter is adjusted directly and control loop is simplified in this algorithm. It is based on the slope of the PV module power curve and are zero at the MPP, positive on the left side and negative on the right hand side of MPP .The flow chart of the incremental conductance algorithm is shown in Fig. 5. The principle of the INC algorithm is to increase or decrease the voltage by adjusting the duty cycle based on the step size $\Delta \mathrm{D}$. The step size can be adjusted automatically by means of a feedback PI controller and can achieve more power and efficiency. The perturbation step size $\Delta \mathrm{D}$ is varied and depends upon the difference between feedback PI controller fD and last instant D from INC algorithm. The proposed method achieves reduced oscillation around the MPP and stable operation of the PV panel. . 


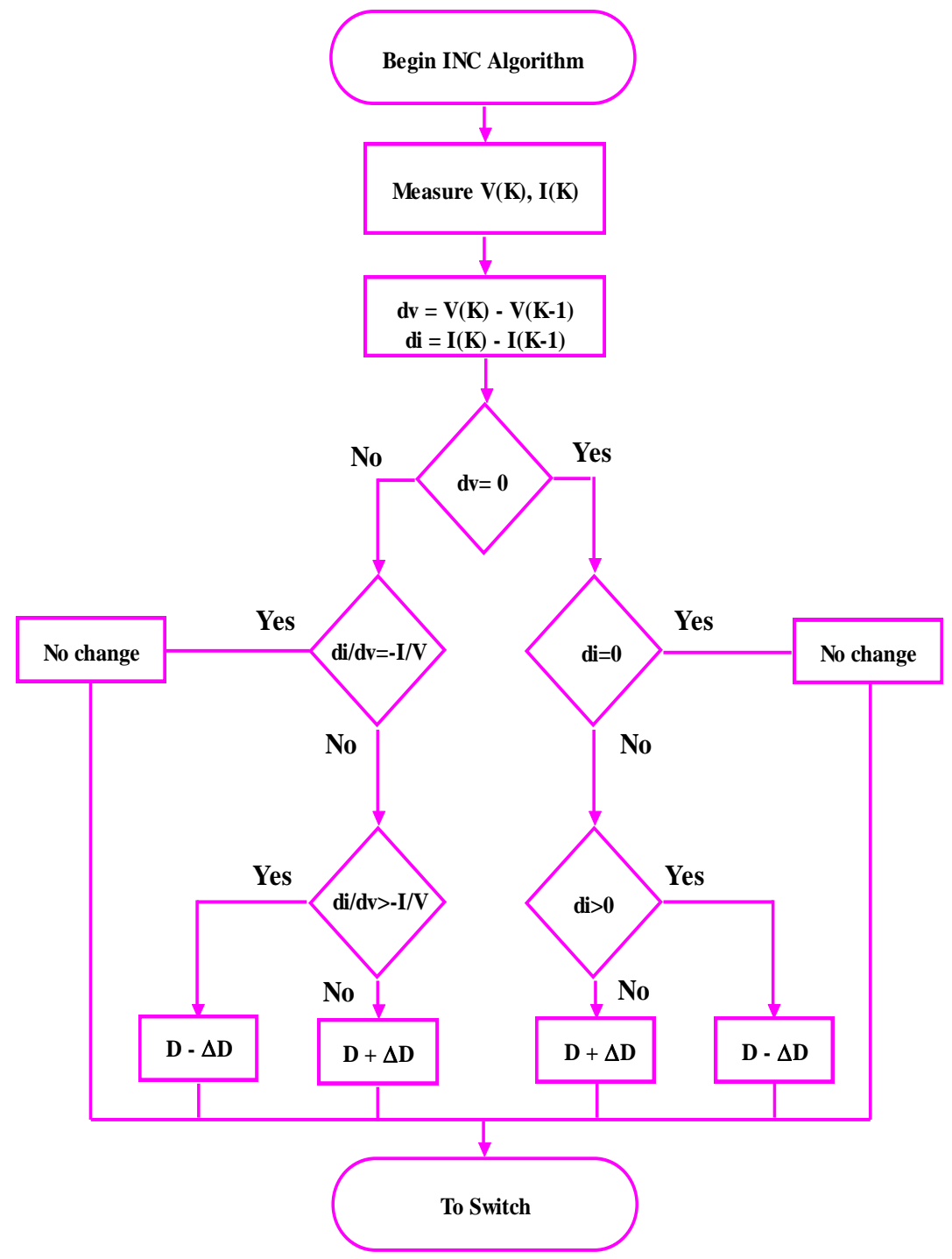

Fig 5:- Flow chart for Incremental \& Conductance Method

\section{Pv Fed Asymmetrical Binary Multilevel Inverter:-}

The renewable energy is an increasingly important part of power generation. The block diagram of the solar fed inverter system is as shown in Fig.6.PV panel is fed as input to the MLI through the DC-DC converter. Binary Hbridge cascaded MLI consists of two H-bridges and its SIMULINK model is shown in the Fig.7. The H-bridges are fed from the PV panels of $21 \mathrm{~V}$ and $42 \mathrm{~V}$ each through a DC-DC converter. The $42 \mathrm{~V}$ are obtained by connecting two PV modules in series. The multicarrier PWM switching strategy uses 6 triangular carriers and one sine wave reference signal is shown in Fig.8. Among the different multi-carrier based MLI PWM strategies PD, POD and APOD are developed and simulated in MATLAB-Simulink. 


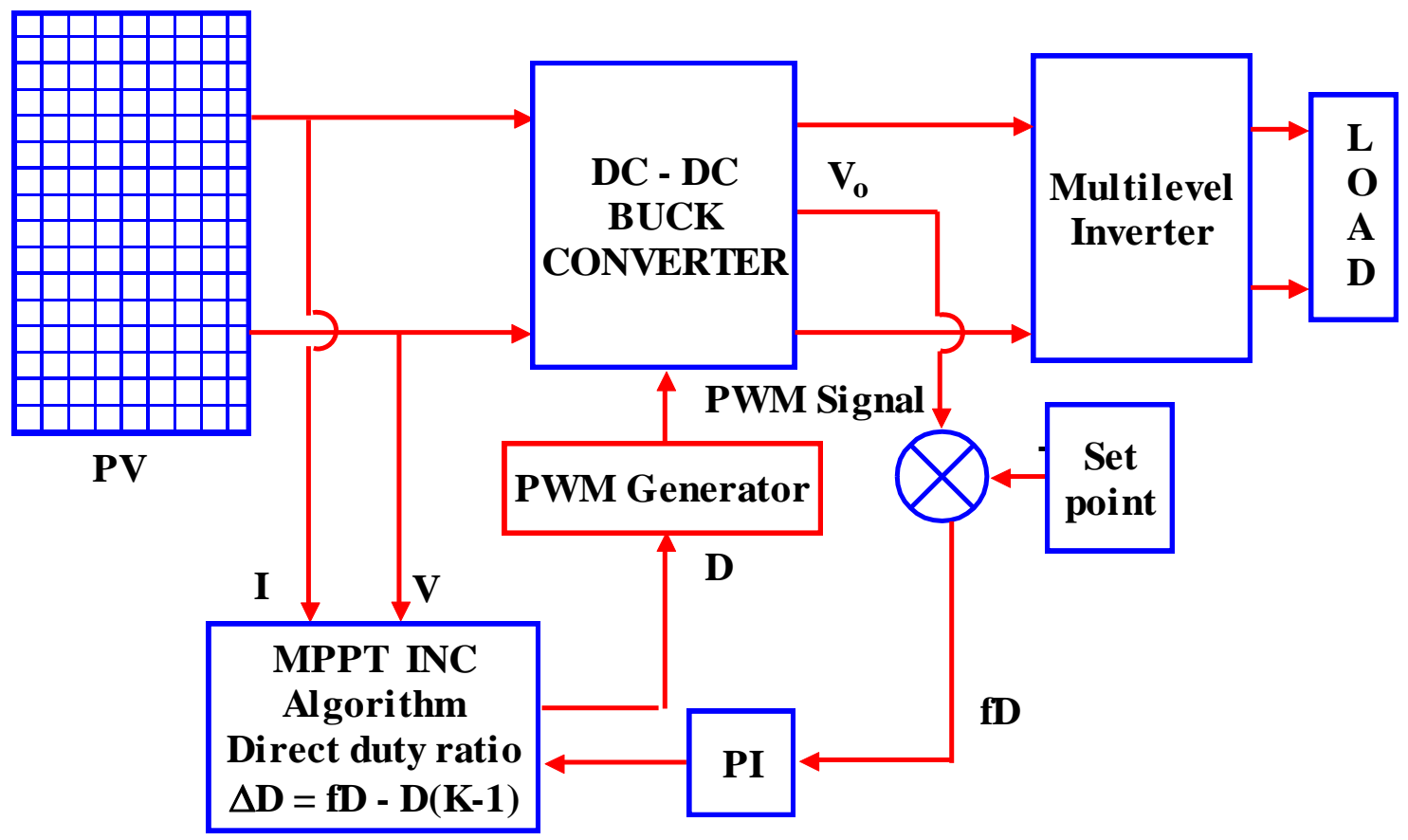

Fig. 6:- Block Diagram of PV Fed Multilevel Inverter

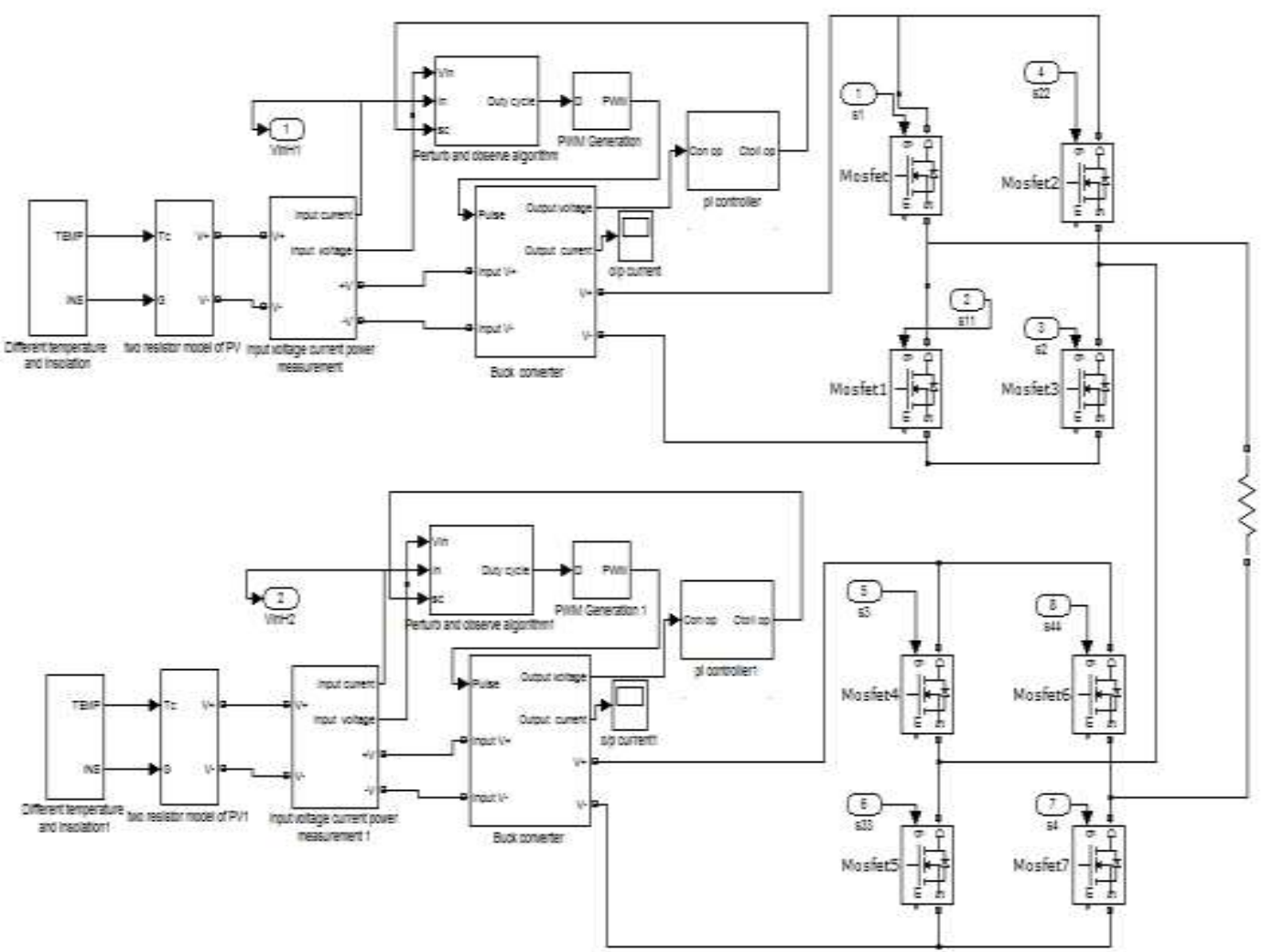

Fig. 7:- Simulink block diagram PV Fed Multilevel inverter 


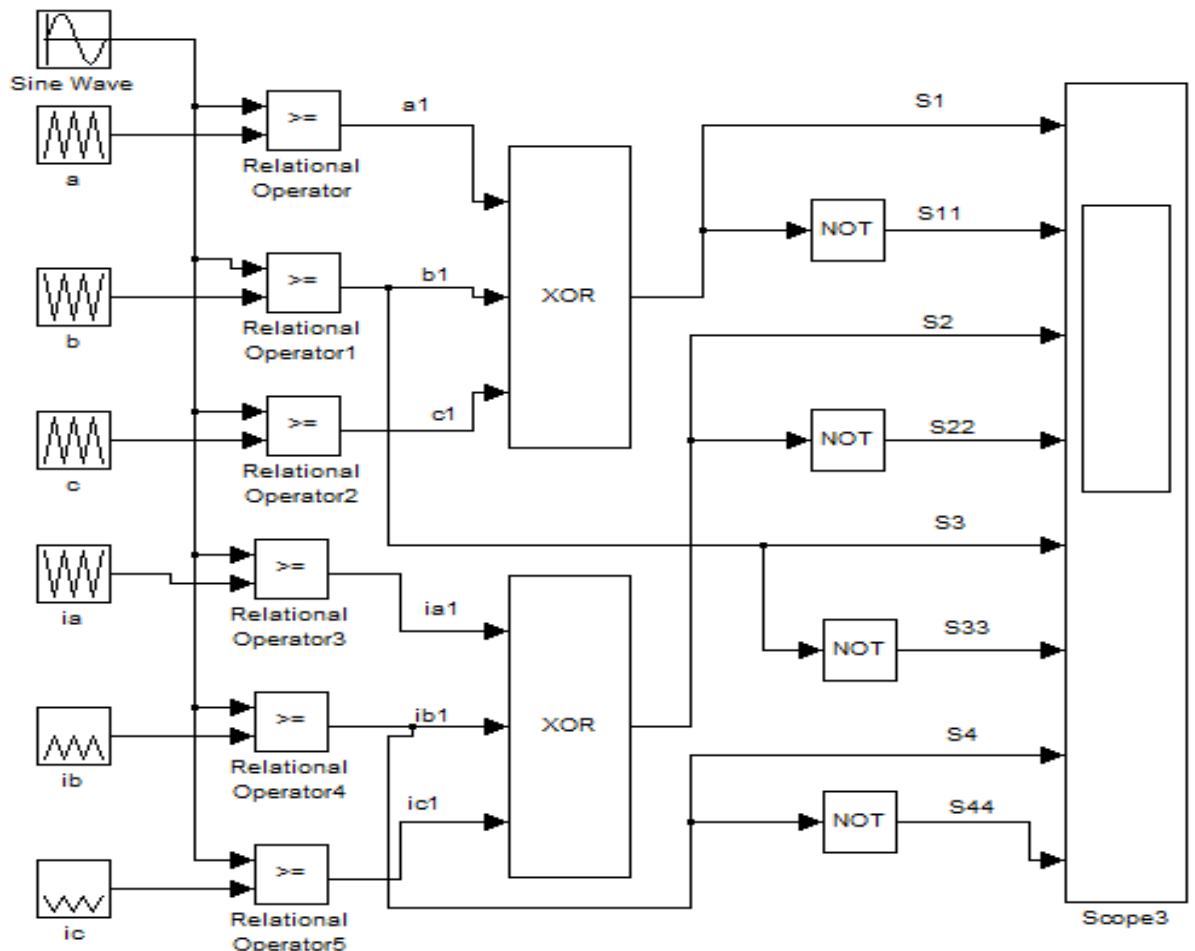

Fig. 8:- SIMULINK block diagram of APOD-PWM

\section{Simulation Results:-}

Fig.9 shows the continuously varying temperature and irradiation of PV module.Fig 10shows the PV output of converter 1 and converter2.Fig.11 shows the simulated sinusoidal reference and triangular multi-carrier used in the various PWM strategies.Fig.12 shows the 7 level AC output current and voltage responses and their corresponding FFT analysis using APOD PWM strategy. Total Harmonic Distortion is found to be $21.37 \%$ for the varying temperature and insolation in PV module. Table 3 shows performance evaluations of THD\%,Vrms, Vpeak,Irms,Ipeak and crest factor for PD,POD,APOD PWM strategy.
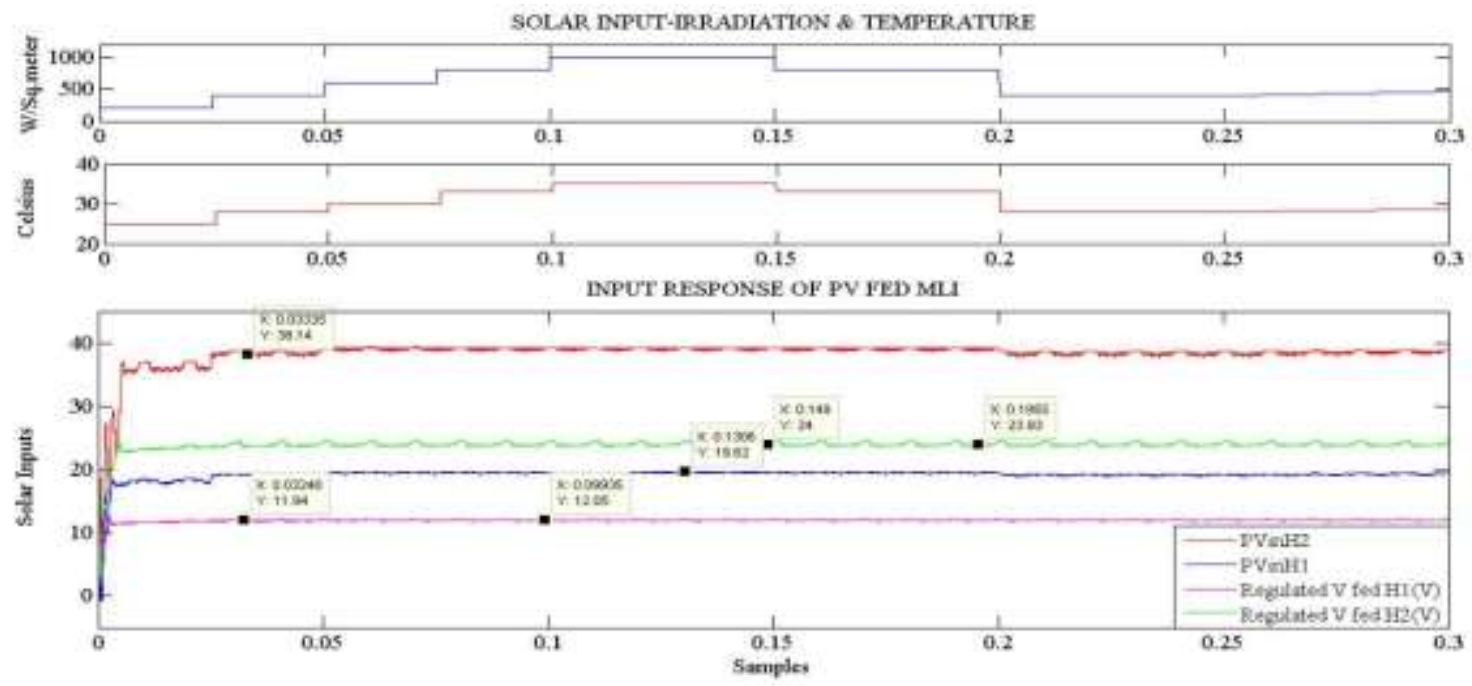

Fig 9:- Simulated solar input and input response of PV fed MLI 


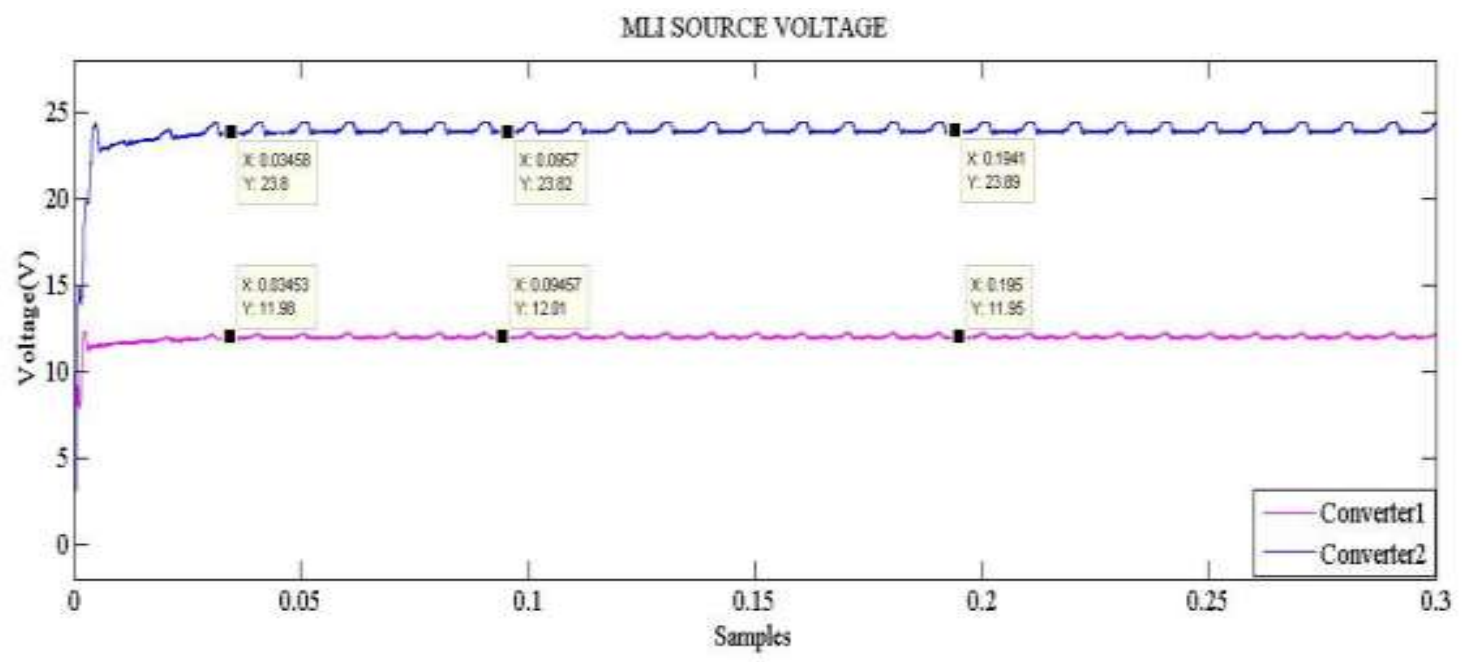

Fig10:- Simulated output response of MLI source voltage.

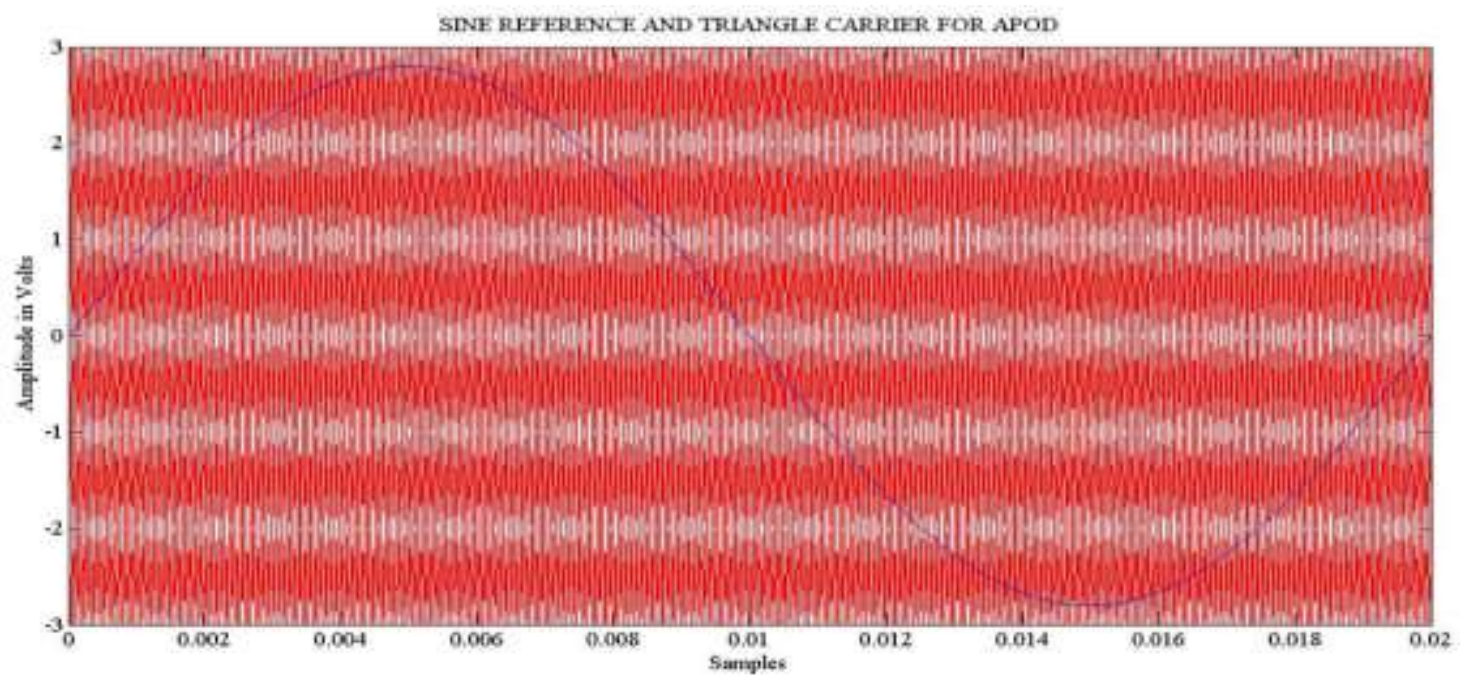

Fig. 11:- Simulated sine reference and triangular multi-carriers

Selected signal: 15 cycles. FFT window (in red): 1 cycles

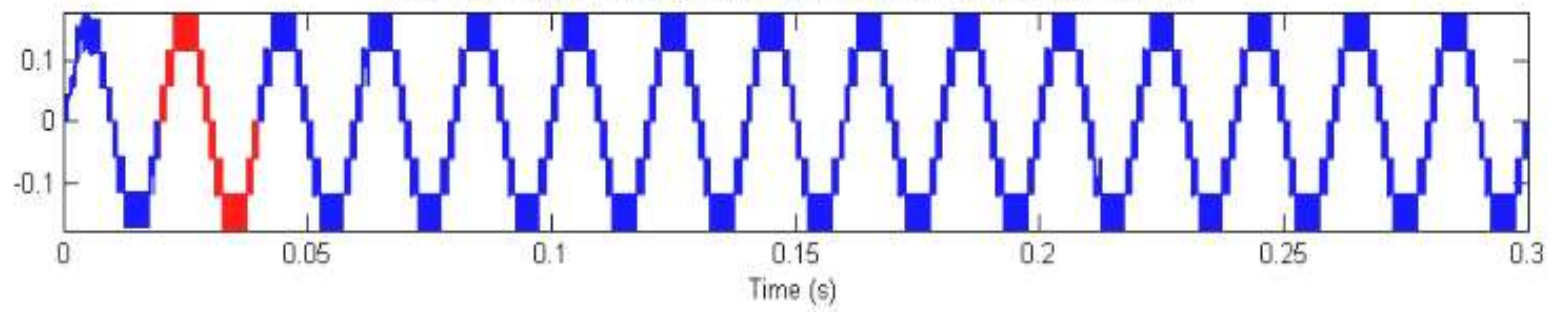




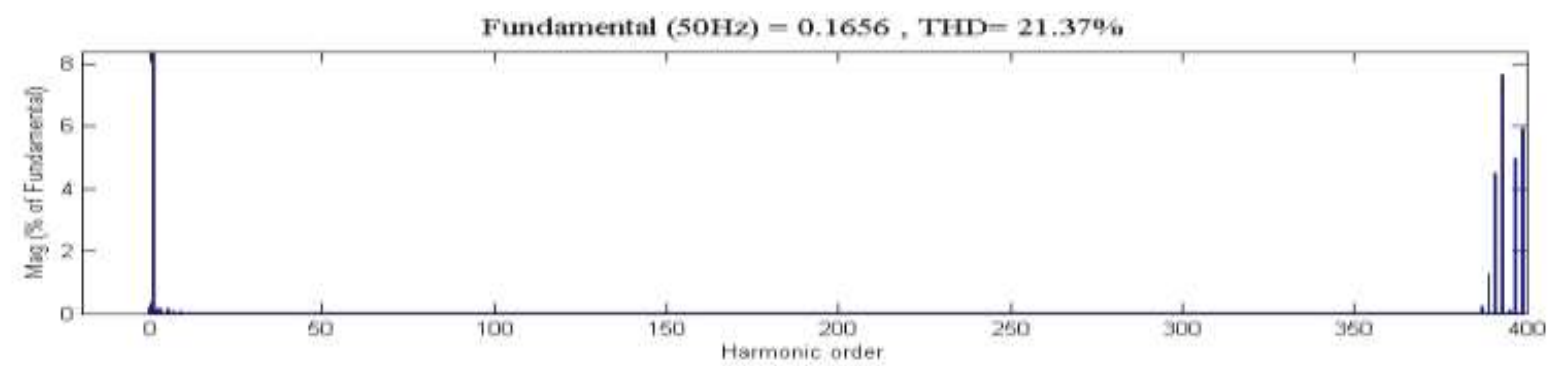

Selected signal: 15 cycles. FFT window (in red): 1 cycles

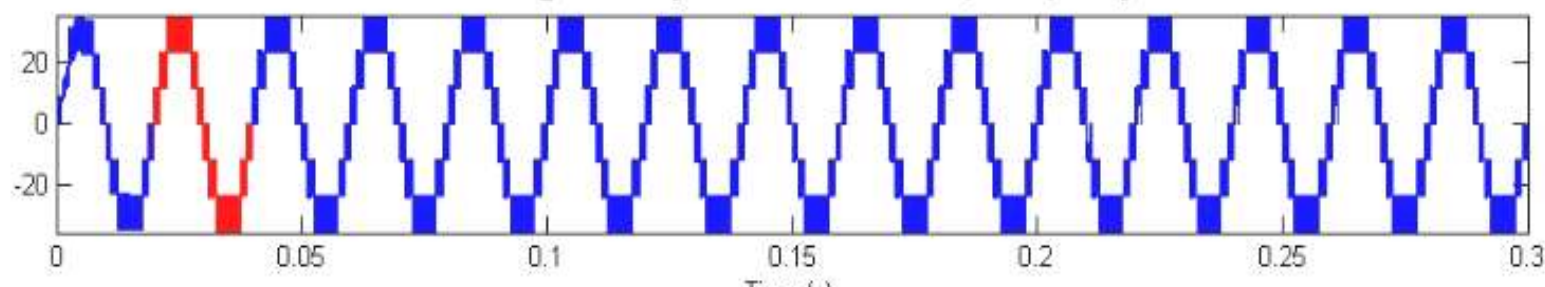

Fundamental $(50 \mathrm{~Hz})-33.12, \mathrm{THD}-21.37 \%$

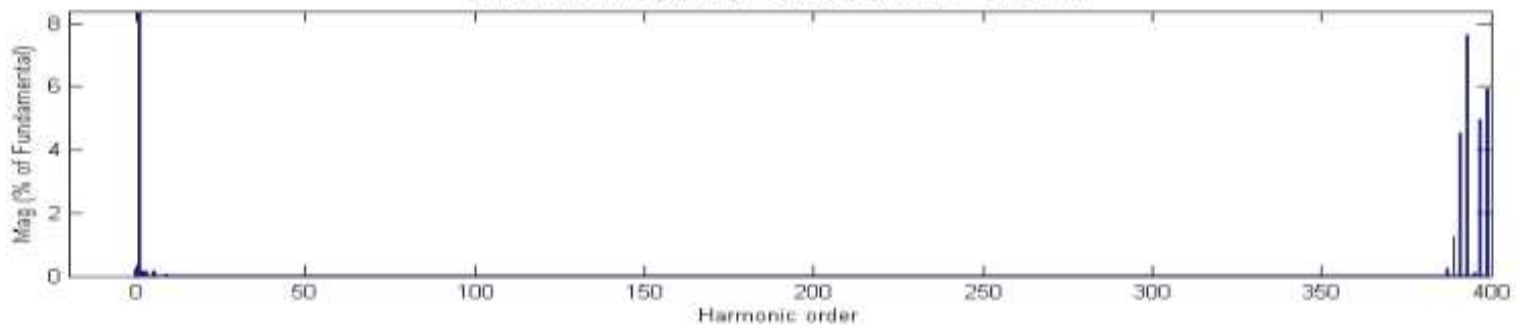

Fig 12:- MLI load current and voltage response and corresponding FFT analysis

Table 3:- Simulated Performance Evaluations of 7 Level BHCMLI

\begin{tabular}{|c|c|c|c|}
\hline Parameters & PD & POD & APOD \\
\hline THD\% & 21.35 & 21.28 & 21.37 \\
\hline Vpeak & 33.5 & 33.49 & 33.1 \\
\hline Vrms & 23.7 & 23.6 & 23.4 \\
\hline Ipeak & 0.16 & 0.16 & 0.16 \\
\hline Irms & 0.11 & 0.11 & 0.11 \\
\hline Crest factor & 1.41 & 1.41 & 1.41 \\
\hline
\end{tabular}

\section{Conclusion:-}

The simulation results show the possibility of AC power generation from the DC renewable PV source by using the asymmetrical MLI. The advantage of asymmetric MLI is the reduction in THD\% of the responses by producing an output resembling the sine wave.

\section{References:-}

1. Ghassami, A., Sadeghzadeh, S.M. and Soleimani, A. (2013):A high performance maximum power point tracker for pv systems. International Journal of Electrical Power \& Energy Systems., Vol 53: pp. 237-243.

2. Zegaoui, A., Aillerie, M., Petit, P., Sawicki, J.P. Charles, J.P. and Belarbi, A.W. (2011):Dynamic behaviour of pv generator trackers under irradiation and temperature changes. Solar Energy., Vol 85: pp. 2953-2964.

3. Gonzalezmoran, C., Arboleya, P., Reigosa, D., Díaz, G. and Aleixandre, J.G. (2009): Improved model of photovoltaic sources considering ambient temperature and solar irradiation. IEEE PES/IAS Conference on Sustainable Alternative Energy., Vol 7: pp. 1-6.

4. He, Q., and Zhao, Y., (2010): The design of controller of buck converter. International Conference on Computer Application and System Modeling., Vol 15: pp. 500-504.

5. Villalva, M.G. Gazoli, J.R. and Filho, E.R. (2009): Analysis and simulation of the p\&o mppt algorithm using a linearized PV array model. 10th Brazilian Power Electronics Conference COBEP., Vol 82: pp. 112-119. 
6. Hassanzadeh, A., Monfared, M., Golestan, S. and Dowlatabadi, R. (2011): Small signal averaged model of dc choppers for control studies. International Conference on Electrical Engineering and Informatics.,pp. 1-4.

7. Chithra, M., and Bharathidasan, S.G. (2011):Analysis of cascaded h bridge multilevel inverters with photovoltaic arrays, International Conference on Emerging Trends in Electrical and Computer Technology., pp. 442-447.

8. Radan, A., Shahirinia, A.H. and Falahi, M. (2007): Evaluation of carrier based pwm methods for multi level inverters. IEEE International Symposium on Industrial Electronics., pp. 389-394.

9. Rajasekar, S. and Gupta, G. (2011): Photovoltaic array based multilevel inverter for power conditioning, International Conference on Power and Energy Systems., pp. 1-6.

10. Sedghi, S., Dastfan, A. Ahmadyfard, A. (2011):A new multilevel carrier based pulse width modulation method for modular multilevel inverter, IEEE 8th International Conference on Power Electronics and ECCE Asia ICPE \& ECCE., pp. 1432-1439. 